\title{
Problem Solving dengan Metode Identifikasi Variabel berdasarkan Skema: Tinjauan terhadap Formulasi Hukum Pertama Termodinamika
}

\author{
Risti Suryantari \\ Program Studi Fisika, Fakultas Teknologi Informasi dan Sains, Universitas Katolik Parahyangan \\ Jl. Ciumbuleuit No. 94, Gedung 9 1t.1, Bandung 40141 \\ ristisuryantari@unpar.ac.id
}

\begin{abstract}
Abstrak - Metode identifikasi variabel berdasarkan skema merupakan salah satu metode problem solving dalam fisika terkait formulasi. Metode ini telah diterapkan bagi formulasi kecepatan relativistik, serta panjang dan waktu relativistik. Pada penelitian kali ini akan diterapkan metode serupa bagi topik termodinamika,. Hukum Pertama Termodinamika melibatkan tiga variabel yaitu kalor, usaha dan perubahan energi dalam. Terdapat dua jenis proses dalam sistem termodinamika , yaitu kalor dan usaha diberikan pada sistem atau dihasilkan oleh sistem. Pada berbagai buku referensi, hal tersebut dicirikan dengan tanda positif dan negatif. Permasalahan yang ditemui adalah kemungkinan terjadinya kesalahan pada perhitungan, terutama jika siswa tidak menentukan tanda positif atau negatif tersebut dengan benar. Skema akan membantu siswa dalam menyelesaiakan soal terkait formulasi ini, tanpa harus memikirkan tanda positif atau negatif pada variabel kalor dan usaha. Metode ini akan diterapkan pada contoh-contoh soal sederhana dan diimplementasikan terhadap mahasiswa Program Studi Fisika Universitas Katolik Parahyangan Bandung. Hasil penelitian menunjukkan seluruh mahasiswa dapat menyelesaikan soal dengan benar dan berpendapat bahwa metode ini lebih mudah untuk dipahami. Guru atau para pengajar fisika dapat menggunakan metode ini sebagai variasi dalam pembelajaran, sehingga formulasi tidak lagi dianggap sulit dalam fisika.
\end{abstract}

Kata kunci: Identifikasi variabel, problem solving, skema, termodinamika,

Abstract - Variable identification method based on the scheme is a method for solving problems related to the formulation in physics. The method has been applied to the formulation of relativistic velocity, relativistic length and relativistic time. In the present study will apply a similar method to the other topic like thermodynamics. Formulation of the First Law of Thermodynamics involving three variables (heat, work and change in internal energy). There are two types of thermodynamics processes, heat and work is given to system or produced by system. In many book, it is characterized by positive or negative sign. The problem is possibility of error in the calculation especially if students are not determined the sign in the right type. The scheme will be help students to solve the problem without thinking about the positive or negative sign on the heat and work variable. The method will be implemented in a simple examples of problem and apllied to students at Physisc Department, Parahyangan Catholic University Bandung. The results show that all the students can solve problems correctly, and they give an argument that this method is easier to understand. Teachers can use the method as variation in physics learning, so that the formulation is not considered to be a difficult thing in physics.

Key words: Variabel identification, problem solving, scheme, thermodynamics

\section{PENDAHULUAN}

Salah satu parameter keberhasilan studi siswa adalah kemampuan dalam menyelesaian masalah (problem solving), baik pada buku referensi maupun ketika menghadapi ujian. Dalam fisika, seringkali ditemui permasalahan yang cenderung pada akhirnya harus menggunakan formulasi dalam penyelesaiannya. Melihat hal tersebut, maka telah dibuat suatu metode khusus dalam problem solving yang difokuskan untuk menentukan variabel dengan tepat, yaitu dengan membuat satu skema yang dapat diterapkan bagi semua tipe persoalan. Metode tersebut secara khusus telah diterapkan bagi formulasi kecepatan relativistik, serta panjang dan waktu relativistik. Pada pembahasan disajikan cara penyampaian skema, dan petunjuk langkah-langkah penyelesaian pada soal. Skema yang digunakan selalu sama, demikian juga dengan posisi benda dan urutan variabel, dengan demikian siswa mampu menentukan variabel dengan tepat. Metode ini kemudian diterapkan pada perkuliahan fisika dasar, Fakultas Teknologi Industri, Universitas Katolik Parahyangan, dan seluruh mahasiswa dapat menentukan variabel dengan tepat $[2,3,4]$.

Pada penelitian kali ini akan ditepkan metode serupa bagi topik termodinamika, khususnya pada formulasi Hukum 1 Termodinamika. Tujuan dari penelitian ini adalah agar siswa berhasil menentukan variabel dengan tepat pada Formulasi Hukum I Termodinamika dengan membuat skema. Pada akhirnya pemahaman konseptual akan menjadi lebih baik. Untuk menguji metode ini, maka secara langsung akan diimplementasikan terhadap Mahasiswa Program Studi Fisika Universitas Karolik Parahyangan Bandung, dengan menyelesaikan beberapa soal menggunakan metode identifikasi variabel berdasarkan skema Metode ini diharapkan dapat menjadi variasi dalam pembelajaran, 
sehingga formulasi tidak menjadi hal yang dianggap sulit dalam fisika.

\section{LANDASAN TEORI}

Metode identifikasi variabel berdasarkan skema menekankan penentuan variabel dengan tepat melalui sebuah skema. Langkah-langkahnya secara umum adalah dengan melakukan penyederhanaan definisi, membuat skema, menyusun langkah-langkah penyelesaian soal, kemudian menerapkan pada persoalan $[3,4]$

Pada topik kecepatan relativistik diungkapkan definisi variabel kecepatan secara sederhana terkait kecepatan relativistik, formulasinya ditunjukkan oleh persamaan 1 , dimana $\mathrm{v}$ adalah kecepatan benda menurut kerangka diam (kerangka diam yang sering muncul dapat berupa bumi atau laboratorium), u' adalah kecepatan suatu benda menurut benda lain yang bergerak, dan $\mathrm{v}$ adalah kecepatan benda lain menurut kerangka diam. Kerangka diam ini seringkali dituliskan bumi atau laboratorium [3].

$$
u=\frac{u^{\prime}+v}{1+\frac{u^{\prime} v}{c^{2}}}
$$

Skema ditunjukkan oleh gambar 1

\section{$[5]$.}

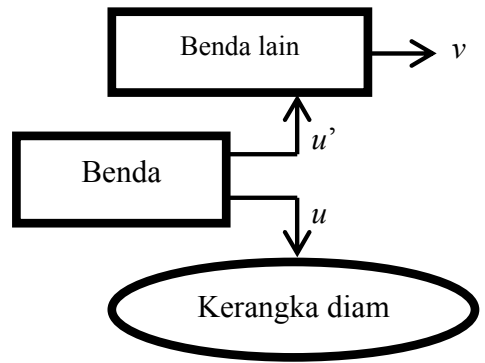

Gambar 1: Skema formulasi kecepatan relativistik

Pada contoh penyelesaian soal, diberikan langkah-langkah sebagai berikut [3]:

a) Tentukan benda yang diukur oleh dua pengamat dan tentukan benda yang diukur oleh satu pengamat.

b) Buat skema seperti gambar 1, tuliskan angka-angka yang diketahui pada skema.

c) Tuliskan variabel $(u, u$ ' atau $v)$ sesuai dengan Gambar 1 (Urutannya dari atas ke bawah selalu $v, u, \quad u$ ').

d) Lakukan perhitungan.

Persamaan untuk pemuaian waktu, ditunjukkan oleh persamaan (1), dengan definisi $\Delta t_{0}$ adalah waktu proper (waktu wajar) untuk menjelaskan interval waktu $\Delta t_{0}$ diantara dua peristiwa yang terjadi pada titik yang sama. Sedangkan $\Delta t$ adalah interval waktu yang melibatkan peristiwa-peristiwa yang terjadi pada titik-titik ruang yang berbeda. Persamaan (2) menunjukkan bahwa pengamat akan mengukur setiap jam berdetak lebih lambat jika jam itu bergerak relatif terhadap pengamat itu, karena $v$ lebih kecil dari $c$ ( $v$ adalah laju kerangka kedua relatif terhadap kerangka diam) [5].

$$
t=\frac{\Delta t_{0}}{\sqrt{1-\frac{v^{2}}{c^{2}}}}
$$

Persamaan untuk kontraksi panjang, ditunjukkan oleh persamaan (3), dengan definisi $l_{0}$ adalah panjang proper (panjang wajar) yaitu panjang yang diukur dalam kerangka dimana benda itu diam (kerangka diam dari benda). Sedangkan $l$ adalah panjang yang diukur dalam kerangka lain yang bergerak relatif terhadap kerangka diam [5].

$$
l=l_{0} \sqrt{1-\frac{v^{2}}{c^{2}}}
$$

Persamaan (3) menunjukkan bahwa pengamat akan mengukur panjang dalam kerangka yang relatif bergerak terhadap kerangka diam selalu lebih pendek daripada ketika diukur dalam kerangka diam dari benda tersebut [5]. Gambar 2 dan 3 menunjukkan skema untuk persoalan panjang dan waktu relativistik [4].

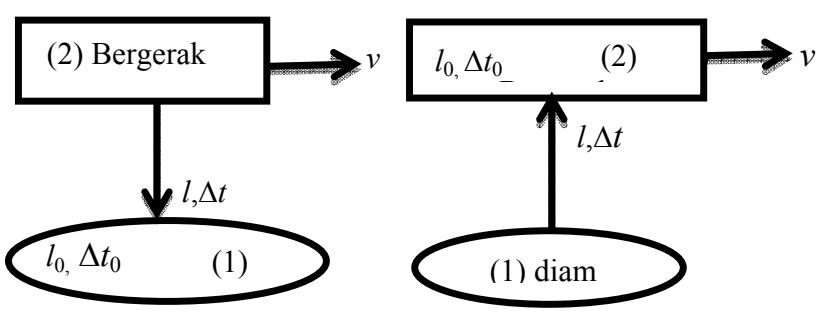

(a)

(b)

Gambar 2 : Skema untuk persoalan panjang dan waktu relativistik (a) 1 menurut 2 (b) 2 menurut 1

Pada penelitian kali ini akan diterapkan metode serupa pada topik termodinamika, khususnya Hukum Pertama Termodinamika. Termodinamika merupakan salah satu topik dalam fisika yang secara umum membahas mengenai fenomena termal yang didefinisikan dalam parameter suhu, kalor dan energi dalam. Hukum Pertama Termodinamika merupakan suatu persamaan kekekalan energi yang melibatkan variabel kalor, usaha dan energi dalam. Konsekuensi penting dari hukum ini adalah adanya nilai energi dalam yang ditentukan oleh keadaan sistem. Dalam berbagai referensi, seringkali diformulasikan seperti persamaan (4) $[1,5,6]$.

$$
Q=\Delta U+W
$$

$Q$ menyatakan kalor, $\Delta U$ menyatakan perubahan energi dalam, dan $W$ menyatakan usaha. Ketiga besaran tersebut memiliki satuan joule $[1,5,6]$.

Dalam berbagai referensi, seringkali ditekankan untuk memperhatikan apakah kalor dan usaha tersebut diberikan pada sistem atau dihasilkan oleh sistem. Untuk membedakannya digunakan tanda positif dan negatif, 
sebagai berikut: $Q$ bernilai positif bila kalor masuk atau diberikan ke sistem, $Q$ bernilai negatif bila kalor dihasilkan oleh sistem, $W$ bernilai positif bila usaha diberikan ke sistem, $W$ bernilai negatif bila usaha dihasilkan oleh sistem. Sementara energi dalam memiliki kemungkinan dapat meningkat atau menurun, sehingga $\Delta U$ bernilai positif bila terjadi kenaikan energi dalam dan $\Delta U$ bernilai negatif bila terjadi penurunan energi dalam $[1,5,6]$.

Permasalahan yang ditemui dalam kelas fisika adalah, ketika tanda positif atau negatif tidak diberikan dengan tepat dan konsisten maka terdapat kemungkinan besar terjadi kesalahan pada perhitungan hasil akhir. Oleh karena itu akan dibuat skema yang dapat membantu siswa dalam menyelesaiakan soal terkait formulasi ini, tanpa harus memikirkan tanda positif atau negatif pada variabel $Q$ dan $W$. Skema tersebut akan diterapkan pada contoh-contoh soal sederhana.

\section{METODE PENELITIAN}

Dalam penelitian ini akan dibuat skema melalui tinjaun literatur, kemudian diterapkan dalam persoalan sederhana terkait Hukum Pertama Termodinamika. Untuk menguji metode ini, sejumlah mahasiswa Program Studi Fisika Universitas Karolik Parahyangan Bandung diberikan soal dan diminta mengerjakan dengan menggunakan metode identifikasi variabel berdasarkan skema. Mahasiswa juga diminta menuliskan pendapat terkait metode ini. Hasil nilai dan pendapat mahaiswa kemudian dianalisis.

\section{HASIL DAN PEMBAHASAN}

\section{A. Skema dan penerapan pada soal}

Formulasi Hukum Termodinamika 1 dengan metode Identfikasi variabel berdasarkan skema secara umum adalah dengan membuat sebuah skema sederhana, ditunjukkan oleh gambar.

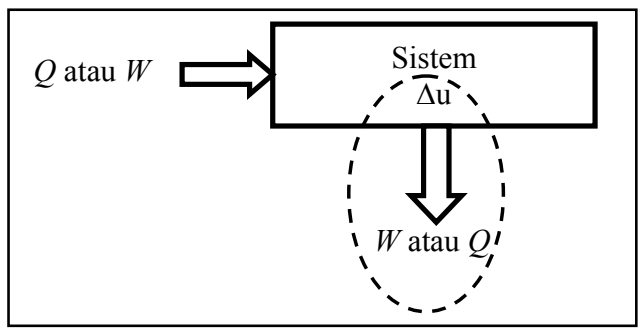

Gambar 3: Skema untuk hukum pertama termodinamika

Penjelasan yang diberikan kepada siswa sebagai berikut:

a) Buat skema seperti gambar. Tanda panah ke kanan menunjukkan apa yang diberikan ke sistem. Tanda panah ke bawah menunjukkan apa yang dihasilkan oleh sistem. b) Tuliskan simbol besaran yang diberikan ke sistem di sebelah kiri tanda panah ke kanan $(Q$ atau $W$ ) dan yang dihasilkan oleh sistem di sebelah bawah tanda panah ke bawah $(Q$ atau $W)$.

c) $\Delta U$ selalu letakkan di tengah (pada sistem).

d)Tulis dari atas ke bawah, maka formulasinya adalah $Q=\Delta U+W$ atau $W=\Delta U+Q$

Berikut disajikan contoh soal dan penyelesaian $[1,5,6]$.

1. Sejumlah gas ideal pada suhu konstan diberikan usaha $2700 \mathrm{~J}$ hingga volumenya mengembang. Bila tidak ada perubahan energi dalam, berapa energi yang dipindahkan oleh kalor ke lingkungannya selama proses tersebut?

Skema:

Formulasi:

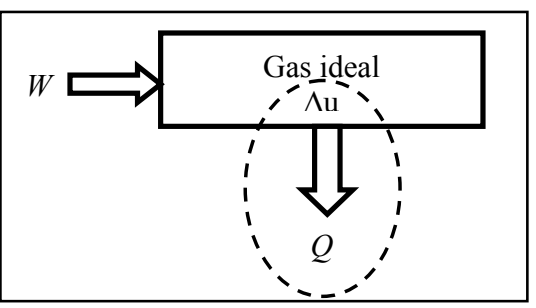

$2700 J=0+Q$

$$
Q=2700 J
$$

2. Batang tembaga dipanaskan pada tekanan atmosfer. Usaha yang dilakukan oleh batang tembaga pada atmosfer sekitar 0,017J. Bila kenaikan energi dalam dari tembaga tersebut adalah $1.200 \mathrm{~J}$, berapa jumlah energi yang dipindahkan ke batang tembaga oleh kalor?

Skema:

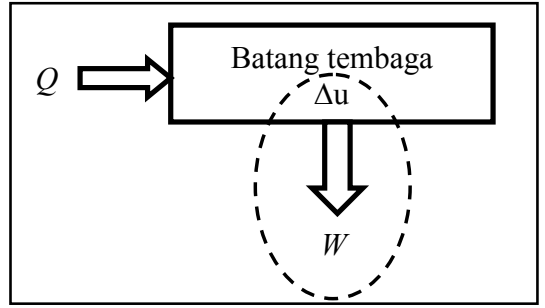

Formulasi:

$$
Q=\Delta U+W=1.200 J+0,017 J=1.200,017 J
$$

3. Sebuah gas dimampatkan pada tekanan tetap, pada proses ini $400 \mathrm{~J}$ energi keluar dari gas dalam bentuk kalor. Bila Usaha yang dilakukan pada gas adalah sebesar 400.000 J, berapa perubahan energi dalam gas?

Skema:

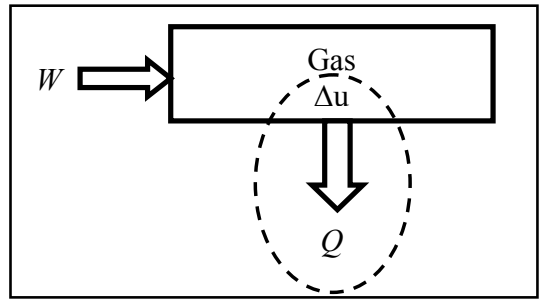


Formulasi:

$$
\begin{gathered}
W=\Delta U+Q \\
400.000 \mathrm{~J}=\Delta U+400 \mathrm{~J} \\
\Delta U=400.000 \mathrm{~J}-400 \mathrm{~J}=399.600 \mathrm{~J}
\end{gathered}
$$

4. Perubahan energi dalam gas yang bergerak dari titik A ke $\mathrm{B}$ adalah $800 \mathrm{~J}$. Usaha yang dilakukan oleh gas adalah 500J. Berapa energi yang harus ditambahkan pada gas oleh kalor ketika bergerak dari titik A ke B tersebut?

Skema:

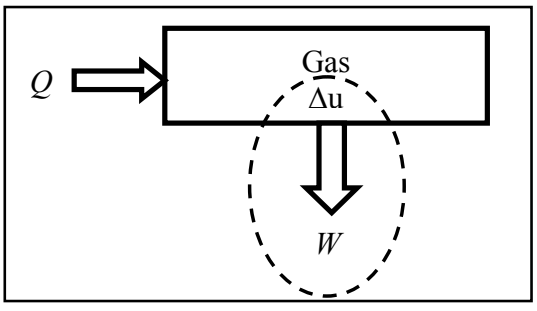

Formulasi:

$Q=\Delta U+W=800 J+500 J=1.300 J$

5. Sebuah sistem termodinamika melakukan sebuah proses dimana energi dalamnya berkurang sebesar 500J. Pada waktu yang sama, $220 \mathrm{~J}$ usaha dilakukan pada sistem tersebut. Carilah energi yang dipindahkan ke luar sistem dalam bentuk kalor!

Skema:

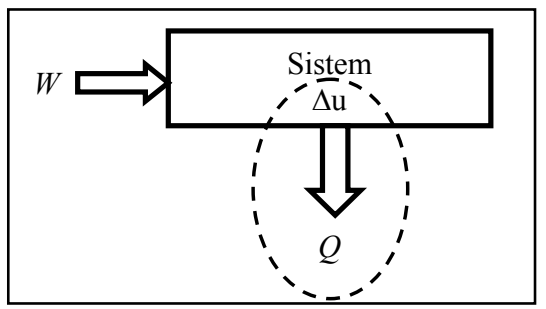

Formulasi:

$$
\begin{gathered}
W=\Delta U+Q \\
220 J=-500 J+Q \\
Q=220 J+500 J=720 J
\end{gathered}
$$

\section{B. Hasil pengujian metode terhadap mahasiswa}

Soal yang diberikan berjumlah lima buah seperti pada contoh soal. Berdasarkan hasil pengerjaan soal, seluruh mahasiswa dapat mengerjakan lima soal dengan benar. Berdasakan hasil pendapat yang dituliskan oleh mahasiswa terkait metode ini, seluruh mahasiswa mengungkapkan bahwa metode ini lebih mudah dipahami.

\section{KESIMPULAN}

Metode identifikasi variabel berdasarkan skema dapat diterapkan dalam topik termodinamika dan dapat dijadikan salah satu referensi metode sebagai variasi dalam pembelajaran fisika.

\section{UCAPAN TERIMA KASIH}

Terimakasih kepada LPPM Universitas Katolik Parahyangan Bandung atas dana penelitian dan mahasiswa Program Studi Fisika Universitas Katolik Parahyangan Bandung atas kerjasama dalam penelitian ini.

\section{PUSTAKA}

[1] Douglas C. Giancoli, Physics Principle With Application, 6th edition, Pearson Education, Inc, 2005.

[2] M.A. Yousuf, \& R.M. Chaveznava, Solving Physics Problems Using Variable Flow Diagrams, International Conference on Engineering Education, Pécs-Budapest, Hungary, July 2008, page 27-31.

[3] Suryantari, R, Problem Solving dengan Metode Identifikasi variabel berdasarkan Skema: Tinjauan terhadap Formulasi Kecepatan Relativistik, Makalah disajikan dalam Simposium Nasional Inovasi Pembelajaran dan Sains (SNIPS) 2012, Intitute Teknologi Bandung, 7-8 Juni 2012.

[4] Suryantari, R, Problem Solving dengan Metode Identifikasi variabel berdasarkan Skema: Tinjauan terhadap Formulasi Panjang dan Waktu Relativistik, Makalah disajikan dalam Simposium Fisika Nasional XXV, Meningkatkan Inovasi melalui Pengembangan Riset dan Edukasi Fisika, Palangkaraya, 19-20 Oktober 2012.

[5] Young \&Freedman, Fisika Universitas, edisi 10, alih bahasa oleh Pantur Silaban ITB, Erlangga, 1999.

[6] Serway, R.,\& Jewett, W, Fisika untuk Sains dan Teknik, edisi 6, alih bahasa oleh Sungkono, C, Salemba Teknika, 2010. 